\title{
A proposed strategy depending on learning patterns for the development of teaching skills of the student / teacher in teaching kinetic education
}

\author{
By \\ Dr. Wafaa Mohamed Adel Elseifi
}

\begin{abstract}
Assistant Professor, Department of Curriculum and Instruction, Faculty of Physical Education for Girls in Cairo, Helwan University, Egypt,
\end{abstract}

Abstract The research aims to build a proposed strategy based on preferred types for the way of learning (visual - auditory - kinetic) and to identify the effectiveness in the development of teaching skills to teaching kinetic education, which found that there is a decline in its performance. The researcher used the experimental method using the before and after measurements test on a sample of first year students who were chosen intentionally and random and they are 45 students, divided into three experimental groups according to the measuring instrument for preferred learning, and a control group. Applying the strategy took three months by a rate of 12 educational units for each group and the time per unit is 90 minutes. the search tools are (a tool to measure the preferred types for the way of learning, survey to renew the most important teaching skills for teaching kinetic learning, card of note to evaluate the performance of students in teaching skills under research) prepared by the researcher. The study showed the effectiveness of the proposed strategy in the development of teaching skills for teaching kinetic education and the superiority of the three experimental groups that learned according to the learning style of each student over the control group in the axes of evaluation card.

Keywords: strategy-learning learning methods - teaching skills - kinetic education

\section{INTRODUCTION}

The planning to prepare efficient teacher is one of the most important recent trends in the development of teacher preparation programs, as attention now is focused on the functions of the teacher, analyzing it, preparing him to do it, and focusing on its preparation on the practical side by exposing him to practical Situations that he practice through group of skills that qualify him to lead the educational process, as the success in the process of teaching requires to be excellent in teaching skills in order to lead the educational situation because the student who will be a teacher pass by a particular program before being a teacher, like the skills of planning implementation and evaluation that contribute in improving the teacher's performance.

According to the growing interest by teaching skills and the need for its availability at the student that will be a teacher, number of studies tried to reach the best ways and means to develop the teaching skills of students as well as the preparation of programs to develop and refine teaching skills according to previous studies (David, 2002; Robert, 2001; Abdel Latif, 2000) which dealt with the use of different studied the impact of the media education on learning teaching skills, and dealt with studying the impact of cooperative 
learning method and self-learning style on improving the efficiency of teaching at student

who will be a teachers and by reference to those studies, in spite of the multiplicity of objectives and areas, the researcher there is no one study dealt with the importance of the classification of students depending on what type they prefer and its impact on the extent of progress in the acquisition of teaching skills in spite of studying it in the field of teaching foreign language and some theoretical subjects. Knowing of learning styles for learners help in determining the most appropriate techniques and teaching strategies that are appropriate to the personal characteristics of learners (Mixon, 2004) Therefore, the researcher depended on the preferred way of learning because of its connection of studying individual skills as it requires studying auditory and visual senses in which a learner receive, interpret and store information. If the student is aware of the type that he prefers this will help him to feel that he achieved something, which develop the sense of the educated skill and generally will help to use various means of education and teaching for students in ways that meet there types of learning to overcome the learning difficulties experienced by some students who have different style of teaching rather than her teacher, and this classification allows $f$ them to learn according to the style they prefer in learning (Hammouda, 2007). So, this will create effective communities for learning is which all learners needs can be achieved. In this regard, referred that the knowledge of teachers by the types of learning of their students will enable them to provide learners with strategies to suit their preferences, and help them to overcome the difficulties of the study, in addition to helping them on using their abilities and preparations to the highest degree (Qamati, 2000)

\section{Statistical characterization of the sample}

The researcher found the statistical characterization of the sample in terms of consistency - consistency of sample in the variables (Age - Height - Weight - intelligence - the performance level of teaching skills under research), and it shows the moderation in the distribution of the sample in all the variables under research, and the elements of skew ranged between $+3,-3$, in addition that there were no differences between the experimental research groups in the research variables, which refers to the equalization of the research sample.

In spite of the recommendations that encourage of considering the preferred types for the way of learning, but status of these recommendations by being under implementation is like the missed link in the researches that care about the improvement of teaching methodologies. Therefore, researcher try to start in scientific formulate that help in using the concept of preferred learning style for the students in spite of improving the process of training on teaching skills and what can be reflected on the development of the educational process for the preparation of the student / teacher to teach the skills of kinetic education, which was found that there is a decline in the performance of the student / teacher through the construction of a proposed strategy based on diagnosing preferred type for the way of learning for the students and to identify its effectiveness in the development of teaching skills for teaching kinetic education. 


\section{METHOD}

\section{Research Methodology}

- Analytical and descriptive approach to study and analysis of previous researches and studies to deal with the issues related to the subject of current research, and studying the results.

- The researcher used the experimental approach to design the four groups (three experimental and one supervisory), and pre and post measurements for the groups.

\section{Research community:}

Represents the first year students in the Faculty of Physical Education for Girls, Helwan University and who are registered in academic year $(2014 / 2015)$, their number is 283 students.

\section{Research sample}

The sample was selected in intentional random manner of 45 students as a percentage of $(16 \%)$ of the total community of the search and those are the students that the researcher taught them in kinetic education and they are divided to four groups:

- Supervisory group was selected according to the timetable, which was received by the researcher (10) students.

- The first experimental group and its number is (15) students who prefer visual learning tools.

- The second experimental group and its number is (12) students who prefer auditory learning tools.

- The third experimental group and its number is (8) students who prefer kinetic learning tools.

\section{Research Tools}

A survey to know the opinion of the third year students for the most important problems for teaching skills that they faced in the implementation of kinetic education:( appendix1) The researcher has prepared a form to identify the most important problems of teaching skills that face the students of third year at the beginning of their field training in primary schools, and she identified four axes for the survey, then the researcher formulated 40 statements that were distributed as follows:

First Axis: Planning and Performance of kinetic education and measured by (10) statements.

Second Axis: teaching performance and measured by (20) statements.

Third Axis: Personal and measured by (5) statements.

Forth Axis: Evaluation and measured (5) statements.

The scientific transactions as been found for the survey by considering the credibility and stability are as follows:

Credibility: calculated in two ways (content credibility - credibility of configuration premise "-- internal consistency") all the correlation transactions between the survey topics and the axis that it belong to has statistical significance. The calculated value of (R) greater than the values of (R) International $(0.57)$ at the level of (0.05) which shows the credibility of survey.

Survey stability: after checking the survey stability, the stability elements calculated by stability element of

(Cronbach Alpha) that range between $(0.668,0.961)$ and the partial element (spearman Brawn) that range between 
$(0.951,0.797)$ that proves the stability of the survey.

The study to apply the survey of counting the teaching problems after checking the credibility of the form of determining the problems concerning teaching skills and applying it on 42 students from the third year in the faculty of Physical Education for girls in Cairo when they started their training in Primary schools, we found that the importance for the problems of teaching skills ranged between $49.23 \%, 59,52$ which is less that $60 \%$ and this proves that the students skills are so poor when they went to field training.

- A survey to know the expert's opinion to determine the most important axis for teaching skills that the students shall have to teach kinetic education.

The teaching skills were limited in some main axes, the topics of the main axes were determined, the content that suits each of the axes and teaching skills were chosen and they were presented to experts and they deleted, modified and added some other skills. Therefore, the teaching skills were determined as (still under research)

After making the final list for teaching skills, they were presented to the same experts again to check the credibility of the axes and topics content. (appendix1)

- A survey for teaching type - prepared by the researcher, (appendix2)

The researcher made a list to evaluate teaching types in a survey for the students, and by answering it, we can determine the type of each student. After a list to evaluate the teaching types in its first figure and presenting it to experts to modify and add their suggestions and proving the credibility, the researcher made the list of evaluating learning types for students in its final figure, and it included:
List cover: includes "list to identify the list, it goal, instruction about how to answer the list topics and a solved example to show how to record the answer in a separate paper"

List statements: it includes 21

statements as questions in which she considered, the numbering of list topics and pages, organizing the list, organizing the list topics to be answered easily.

The key to mark the answers of each topic forms of three responses for each topic, and each of them shows one of the three types of learning. This key was prepared so that the one who will correct the papers can do that easily.

- A survey to know the experts opinion in teaching methods for each of the learning types "Prepared by researcher":

The researcher made a survey for the newest methods of teaching in kinetic learning, and she studied and analyzed it well and then presented it to experts, until she reached the suitable teaching methods for each type from the experts' point of view:

\section{1- Teaching methods for auditory learning.}

As experts say, replying the call is the best way for auditory learning by using the following methods:

a- The guided discovery

b- Problem solving

2- Teaching methods for visual learning

As experts say, the whole method is the best method for visual learning by using the following methods:

a- The reciprocal style

b- Micro teaching

3- The methods for kinetic learning

As experts say, the partial and progressive method, and the method 
of trying and mistakes are the best for kinetic learning

a- Playing method

- Card note to evaluate the students' performance is under research by the researcher.(appendex3)

The card of note was made to evaluate the students' (samples) teaching skills, so that we can determine the effectiveness of learning unit. 10 experts were asked for their opinions through an interview concerning the main and secondary axes and the topics of each ax. By analyzing their opinions, some modifications happened by deleting some statements and adding other ones, until we reached the final form of the card according to the following steps:

1- Rephrasing the card of note elements

2- Quantifications of marks:

- Excellent 5 marks

- Very good 4 marks

- Good 3 marks

- Pass 2 marks

- Weak 1 mark

3- Finding the scientific transactions for the card

\section{First: card credibility}

A-Content credibility: this happened by presenting the card of note to 10 experts in the curriculums and teaching methods to know their opinions in each item in the card, and the items that received less than $70 \%$ were excluded.

B-Premise configuration: by internal consistency through finding the linking element between the results of each item in the card alone, with the result of the axis that belong to this item.

Secondly: calculating the card of note stability:
After checking the credibility, we shall check the stability by using the "Cronbach Alpha" and "spearman Brawn"

\section{The Survey}

The survey was made on 12 students from first year, from the community of research and others who are not included in the main sample, and this aims to:

- Checking the validity of equipment used

- Making sure that the students can easily understand the written instructions and the statement used in the survey of "learning type"

\section{THE MAIN STUDY}

\section{Pre measurements:}

The pre measurements were applied on the students in the variables mentioned in the research (high- weight- age- the level of teaching the kinetic learning) on $3 / 11 / 2014$

\section{Implementing the suggested strategy, (appendix4)}

The researcher translated the teaching skill which were determined before in learning units according to each type (auditory - visual- kinetic) by 48 learning unit divided into 36 learning unit for the three experimental groups which take into consideration the learning types model that the current study adopt (sensory model) and 12 unit for the supervising group, where the main teaching skills are to be taught, and they were also mentioned before through the learning unit (planning skill and preparing lesson, implementing the lesson skill, evaluating skill and personality) as the following:

- First group prefers the visual learning and they learn by watching $\mathrm{CD}$ which have (skill name, 
definition, points to be considered, a model of how to implement this skill in teaching by excellent students, practicing on the skill and making activities)(appendix4)

- The second group prefers auditory learning and they learn by hearing tapes recorded by the researcher's voice and it includes (success warning, skill name, definition, points to be considered, how to implement this skill, practicing on the skill and making activities)

The third group prefers kinetic learning and they learn by dividing the group into smaller groups to make workshop that includes the guide for studying unit, cards that prepared previously by the researcher which include the kinetic duties that the student

- shall perform and introduce it to the rest of the group by making some small games that result in the teaching skills. In addition, the researcher shall give the students some instructions during the performance, and this happens by using different strategy for each experimental group according to the type of learning and teaching methods that suit each type that is previously determined.

- In the supervisory group, a number of 12 learning unit shall be taught out of the academic day, and they include the same teaching skills under research but as a normal lecture.

\section{- RESULTS}

- Table 1: The significant differences between the pre and post measurements of the first experimental group (visual learning style) of the under research variables $\mathbf{N}=\mathbf{1 5}$

\begin{tabular}{|c|c|c|c|c|c|c|c|c|c|}
\hline \multirow{2}{*}{ variables } & \multirow[b]{2}{*}{ Main axes } & \multicolumn{2}{|c|}{ before } & \multicolumn{2}{|c|}{ post } & \multirow[b]{2}{*}{$\mathbf{F}$} & \multirow[b]{2}{*}{$\mathbf{T}$} & \multirow{2}{*}{$\begin{array}{l}\text { Sig. } \\
\text { level }\end{array}$} & \multirow{2}{*}{$\begin{array}{l}\text { Impro } \\
\text { vemen } \\
\text { t rate }\end{array}$} \\
\hline & & Mean & Std. & Mean & Std. & & & & \\
\hline \multirow{3}{*}{$\begin{array}{l}\text { planning } \\
\text { and } \\
\text { preparation } \\
\text { Lesson }\end{array}$} & Appointing goals & 5.600 & 1.920 & 16.200 & 5.720 & 10.600 & 10.661 & 0.000 & 189.28 \\
\hline & $\begin{array}{l}\text { Preparing and } \\
\text { applying Lesson }\end{array}$ & 8.130 & 2.970 & 16.400 & 5.990 & 8.270 & 10.469 & 0.000 & 101.72 \\
\hline & $\begin{array}{c}\text { The Total planning } \\
\text { and preparation } \\
\text { Lesson }\end{array}$ & 13.730 & 4.847 & 32.600 & 11.710 & 18.870 & 10.644 & 0.000 & 137.43 \\
\hline \multirow{4}{*}{$\begin{array}{l}\text { Implementi } \\
\text { ng lesson }\end{array}$} & Introductory part & 4.000 & 0.655 & 6.470 & 1.060 & 2.470 & 11.457 & 0.000 & 61.750 \\
\hline & Main part & 8.800 & 1.265 & 29.130 & 4.438 & 20.330 & 24.442 & 0.000 & 231.02 \\
\hline & Final part & 4.130 & 0.916 & 6,400 & 0.986 & 2.270 & 14.789 & 0.000 & 54.964 \\
\hline & $\begin{array}{c}\text { The Total } \\
\text { Implementing Lesson }\end{array}$ & 16.933 & 2.520 & 42.000 & 6.325 & 25.067 & 25.499 & 0.000 & 148.03 \\
\hline \multicolumn{2}{|r|}{ Calendar } & 4.733 & 1.223 & 8.467 & 2.446 & 3.734 & 11.825 & 0.000 & 78893 \\
\hline \multicolumn{2}{|c|}{ Personality } & 16.867 & 2.295 & 47.330 & 6.565 & 30.463 & 27.608 & 0.000 & $\begin{array}{l}180 \\
607\end{array}$ \\
\hline \multicolumn{2}{|c|}{$\begin{array}{c}\text { Total measurement of teaching } \\
\text { skills }\end{array}$} & 52.267 & 6.980 & $\begin{array}{c}130.40 \\
0\end{array}$ & 17.410 & 78.133 & 28.950 & 0.000 & $\begin{array}{c}149.48 \\
8\end{array}$ \\
\hline
\end{tabular}

- (T) Tabular value at the moral level $0.05=2.145$

According to the previous, table (1) there were statistical significant differences between the two measurements pre and post of the first experimental group in all research variables directed to post measurement, whereas calculated (T) value more than tabular $(\mathrm{T})$ value as well as the improvement rates ranged between (54.964\%, $231.023 \%)$. 
Table (2): The significant differences between the pre and post measurements of the second experimental group (verbal learning style) of the under research variables $\mathbf{n}=\mathbf{1 2}$

\begin{tabular}{|c|c|c|c|c|c|c|c|c|c|}
\hline \multirow[t]{2}{*}{ variables } & \multirow[t]{2}{*}{ Main axes } & \multicolumn{2}{|c|}{$\begin{array}{c}\text { Pre } \\
\text { measurement }\end{array}$} & \multicolumn{2}{|c|}{$\begin{array}{c}\text { Post } \\
\text { measurement }\end{array}$} & \multirow[t]{2}{*}{$\mathbf{F}$} & \multirow[t]{2}{*}{$\mathbf{T}$} & \multirow{2}{*}{$\begin{array}{l}\text { Si } \\
\text { g. }\end{array}$} & \multirow{2}{*}{$\begin{array}{l}\text { Improv } \\
\text { ement } \\
\text { rate }\end{array}$} \\
\hline & & Mean & Std. & Mean & Std. & & & & \\
\hline \multirow{3}{*}{$\begin{array}{l}\text { planning } \\
\text { and } \\
\text { preparati } \\
\text { on Lesson }\end{array}$} & Appointing goals & 3.75 & 1.485 & 6.583 & 4.295 & 2.833 & 2.927 & $\mathbf{0}$ & 75.547 \\
\hline & $\begin{array}{l}\text { Preparing and } \\
\text { applying Lesson }\end{array}$ & 8.583 & 3.579 & 21.083 & 8.878 & 12.5 & 7.71 & $\mathbf{0}$ & 145.637 \\
\hline & $\begin{array}{c}\text { The Total planning } \\
\text { and preparation } \\
\text { Lesson }\end{array}$ & 12.33 & 5.015 & 27.667 & 11.428 & 15.337 & 8.28 & $\mathbf{0}$ & 124.388 \\
\hline \multirow{6}{*}{$\begin{array}{l}\text { Implemen } \\
\text { ting lesson }\end{array}$} & Introductory part & 3.833 & 0.835 & 11.167 & 1.697 & 7.334 & 23.673 & $\mathbf{0}$ & $\mathbf{1 9 1 . 3 3 8}$ \\
\hline & Main part & 8.083 & 1.505 & 19.833 & 3.07 & 11.75 & 19.435 & $\mathbf{0}$ & 145.367 \\
\hline & Final part & 3.833 & $\mathbf{0 . 9 3 7}$ & 5.75 & 0.866 & 1.917 & 6.665 & $\mathbf{0}$ & 50.013 \\
\hline & $\begin{array}{c}\text { The Total } \\
\text { Implementing Lesson }\end{array}$ & 15.75 & 2.34 & 36.75 & 5.496 & 21 & 23.004 & $\mathbf{0}$ & 133.333 \\
\hline & Calendar & 4.917 & 0.793 & 8.833 & 1.586 & 3.916 & 17.11 & $\mathbf{0}$ & 79.642 \\
\hline & Personality & 15.5 & 2.236 & 44.58 & 6.571 & 29.08 & 23.229 & $\mathbf{0}$ & $\mathbf{1 8 7 . 6 1 3}$ \\
\hline \multicolumn{2}{|c|}{ Tot. measurement of teaching skills } & 48.5 & 6.186 & $\mathbf{1 1 7 . 8 3}$ & 14.85 & 69.33 & 27.605 & $\mathbf{0}$ & 142.955 \\
\hline
\end{tabular}

\section{(T) Tabular value at the moral level $0.05=2.201$}

According to table (2) there were statistical significant differences between the two measurements pre and post of the second experimental group in all research variables directed to post measurement, whereas calculated $(\mathrm{T})$ value more than tabular $(\mathrm{T})$ value as well as the improvement rates ranged between $(50.013 \%, 191.34 \%)$.

Table (3): The significant differences between the pre and post measurements of the third experimental group (kinetic learning style) of the under research variables $n=8$

\begin{tabular}{|c|c|c|c|c|c|c|c|c|c|}
\hline & & \multicolumn{2}{|c|}{ before } & \multicolumn{2}{|c|}{ after } & \multirow[b]{2}{*}{$\mathbf{F}$} & \multirow[b]{2}{*}{$\mathbf{T}$} & \multirow[b]{2}{*}{$\begin{array}{l}\text { Sig. } \\
\text { level }\end{array}$} & \multirow{2}{*}{$\begin{array}{c}\text { Improve } \\
\text { ment } \\
\text { rate }\end{array}$} \\
\hline variables & Main axes & Mean & Std. & Mean & Std. & & & & \\
\hline \multirow{3}{*}{$\begin{array}{c}\text { planning } \\
\text { and } \\
\text { preparation } \\
\text { Lesson }\end{array}$} & Appointing g & 4.750 & 1.832 & 8.875 & 3.399 & 4.125 & 7.105 & 0.000 & 86.842 \\
\hline & $\begin{array}{c}\text { Preparing and applying } \\
\text { Lesson }\end{array}$ & 8.083 & 1.505 & 19.833 & 3.070 & 11.750 & 19.435 & 0.000 & 145.367 \\
\hline & $\begin{array}{r}\text { The Total plannir } \\
\text { preparation Le }\end{array}$ & 13.625 & 5.208 & 29.625 & 11.575 & 16.000 & 7.105 & 0.000 & 117.431 \\
\hline \multirow{6}{*}{$\begin{array}{l}\text { Implementi } \\
\text { ng lesson }\end{array}$} & Introductory $p$ & 3.750 & 1.035 & 10.875 & 1.356 & 7.125 & 10.690 & 0.000 & 190.000 \\
\hline & & 9.000 & 1.069 & & 2.416 & 12.125 & 23.526 & 0.000 & 134.722 \\
\hline & Fil & 3.250 & 1.389 & 6.000 & 0.756 & 2.750 & 7.514 & 0.000 & 84.615 \\
\hline & $\begin{array}{c}\text { The Total } \\
\text { Implementing Lesson }\end{array}$ & 16.000 & 1.852 & 38.000 & 4.408 & 22.000 & 24.274 & 0.000 & 137.500 \\
\hline & Calendar & 4.875 & 0.991 & 8.750 & 1.982 & 3.875 & 11.059 & 0.000 & 79487 \\
\hline & Personality & 15.625 & 2.264 & 42.625 & 6.186 & 27.000 & 19.442 & & $\mathbf{1 7 2 . 8 0 0}$ \\
\hline \multicolumn{2}{|c|}{ Total measurement of teaching skills } & 50.125 & 4.612 & 119.00 & 10.876 & 68.875 & 30.864 & 0.000 & $\mathbf{1 3 7 . 4 0 6}$ \\
\hline
\end{tabular}

(T) Tabular value at the moral level $0.05=2.31$

According to table (3) there were statistical significant differences between the two measurements pre and post of the third experimental group in all research variables directed to post measurement, whereas the calculated $(\mathrm{T})$ value more than tabular $(\mathrm{T})$ value as well as the improvement rates ranged between $(79.487 \%, 190 \%)$. 
Table (4): The significant differences between the pre and post measurements of the control group of the under research variables $\mathbf{N = 1 0}$

\begin{tabular}{|c|c|c|c|c|c|c|c|c|c|}
\hline \multirow[t]{2}{*}{ variables } & \multirow[t]{2}{*}{ Main axes } & \multicolumn{2}{|c|}{$\begin{array}{c}\text { Pre } \\
\text { measurement }\end{array}$} & \multicolumn{2}{|c|}{$\begin{array}{c}\text { Post } \\
\text { measurement }\end{array}$} & \multirow[t]{2}{*}{$\mathbf{F}$} & \multirow[t]{2}{*}{$\mathbf{T}$} & \multirow{2}{*}{$\begin{array}{l}\text { Sig. } \\
\text { level }\end{array}$} & \multirow{2}{*}{$\begin{array}{l}\text { Improve. } \\
\text { rate }\end{array}$} \\
\hline & & Mean & Std. & Mean & Std. & & & & \\
\hline \multirow{3}{*}{$\begin{array}{l}\text { planning } \\
\text { and } \\
\text { preparati - } \\
\text { on Lesson }\end{array}$} & Appointing goals & 3.400 & 1.578 & 4.000 & 1.886 & 0.600 & 3.674 & 0.000 & 17.647 \\
\hline & $\begin{array}{l}\text { Preparing and applying } \\
\text { Lesson }\end{array}$ & 8.100 & 3.573 & 9.600 & 4.427 & 1.500 & 4.881 & 0.000 & 18.519 \\
\hline & $\begin{array}{c}\text { The Total planning and } \\
\text { preparation Lesson }\end{array}$ & 11.500 & 5.105 & 13.600 & 6.293 & 2.100 & 5.547 & 0.000 & 18.261 \\
\hline \multirow{6}{*}{$\begin{array}{c}\text { Implemen } \\
\text { ting } \\
\text { lesson }\end{array}$} & Introductory part & 3.800 & 0.9 & 6.000 & 1.333 & 2.200 & 4.296 & 0.000 & 57.895 \\
\hline & Main part & 7.800 & 2.201 & 11.700 & 1.567 & 3.900 & 9.000 & 0.000 & 50.000 \\
\hline & Final part & 4.000 & 0.816 & 3.700 & 0.675 & 0.300 & 1.152 & 0.000 & 7.500 \\
\hline & $\begin{array}{c}\text { The Total Implementing } \\
\text { Lesson }\end{array}$ & 15.600 & 2.271 & 21.400 & 3.169 & 5.800 & 19.959 & 0.000 & 37.179 \\
\hline & Calendar & 5.000 & 0.943 & 5.600 & 1.430 & 0.600 & 3.674 & 0.000 & 12.000 \\
\hline & Personality & 15.000 & 2.310 & 20.500 & 3.240 & 5.500 & $\mathbf{1 7 . 8 9 7}$ & 0.000 & 36.667 \\
\hline \multicolumn{2}{|c|}{ Total measurement of teaching skills } & 47.100 & 6.871 & 61.100 & 9.158 & 14.000 & 18.418 & 0.000 & 29.724 \\
\hline
\end{tabular}

(T) Tabular value at the moral level $0.05=2.262$

According to table (4) there were statistical significant differences between the two measurements pre and post of the control group in all research variables for the post measurement, whereas the calculated $(\mathrm{T})$ value more than tabular $(\mathrm{T})$ value , but the rates of improvement were weak comparing with improvement rates of experimental groups and ranged between $(7.5 \%, 57.895 \%)$.

Table (5): Significant differences in the dimensional measurement between first experimental group (visual learning style) and control group

\begin{tabular}{|c|c|c|c|c|c|c|}
\hline \multirow{2}{*}{\multicolumn{2}{|c|}{ Dependent Variable }} & \multirow{2}{*}{$\begin{array}{c}\text { (I) } \\
\text { GROUP } \\
\text { Mean }\end{array}$} & \multirow{2}{*}{$\begin{array}{c}(\mathbf{J}) \\
\text { GROUP } \\
\text { Mean }\end{array}$} & Mean & \multirow[b]{2}{*}{$\begin{array}{l}\text { Std. } \\
\text { Error }\end{array}$} & \multirow[b]{2}{*}{ Sig. } \\
\hline & & & & $\begin{array}{l}\text { Difference(I- } \\
\text { J) }\end{array}$ & & \\
\hline \multirow{3}{*}{$\begin{array}{l}\text { planning and } \\
\text { preparation } \\
\text { Lesson }\end{array}$} & $\begin{array}{c}\text { The Total planning and } \\
\text { preparation Lesson }\end{array}$ & 16.200 & 4.000 & 19 & 4.348 & $\mathbf{0}$ \\
\hline & Appointing goals & 16.400 & 9.600 & 12.2 & 1.774 & $\mathbf{0}$ \\
\hline & $\begin{array}{c}\text { Preparing and applying } \\
\text { Lesson }\end{array}$ & 32.600 & 13.600 & 6.8 & 2.863 & 0.057 \\
\hline \multirow{4}{*}{$\begin{array}{l}\text { Implementing } \\
\text { lesson }\end{array}$} & $\begin{array}{c}\text { The Total Implementing } \\
\text { Lesson }\end{array}$ & 6.470 & 6.000 & 20.6 & 2.132 & $\mathbf{0}$ \\
\hline & Introductory part & 29.130 & 11.700 & 0.467 & 0.557 & 0.732 \\
\hline & Main part & 6,400 & 3.700 & 17.433 & 1.341 & $\mathbf{0}$ \\
\hline & Final part & 42.000 & 21.400 & 2.7 & 0.349 & $\mathbf{0}$ \\
\hline \multirow{2}{*}{\multicolumn{2}{|c|}{$\begin{array}{l}\text { Calendar } \\
\text { Personality }\end{array}$}} & 8.467 & 5.600 & 2.867 & 0.8 & 0.003 \\
\hline & & 47.330 & 20.500 & 26.833 & 2.42 & $\mathbf{0}$ \\
\hline \multicolumn{2}{|r|}{ Total } & 130.400 & 61.100 & 69.3 & 5.792 & $\mathbf{0}$ \\
\hline
\end{tabular}

According to table (5) there were statistical significant differences in all dimensional measurement between the first experimental group and control group for the experimental group in the most variables of research except the axes "appointing goalsIntroductory part" whereas the significant level values ranged between $(0.003,00.0)$ and less than the moral level 0.05 , except the significant level in each axes "appointing 
goals- Introductory part" that reached to 0.732 .0 .057 which also more than the moral level (0.05)

Table (6): Significant differences in the dimensional measurement between the second experimental group (verbal learning style) and the control group

\begin{tabular}{|c|c|c|c|c|c|c|}
\hline \multicolumn{2}{|c|}{ Dependent Variable } & $\begin{array}{c}\text { (I) } \\
\text { GROUP } \\
\text { Mean } \\
\end{array}$ & $\begin{array}{c}(\mathbf{J}) \\
\text { GROUP } \\
\text { Mean } \\
\end{array}$ & $\begin{array}{c}\text { Mean } \\
\text { Difference }\end{array}$ & $\begin{array}{l}\text { Std. } \\
\text { Error }\end{array}$ & Sig. \\
\hline \multirow{3}{*}{$\begin{array}{l}\text { planning and } \\
\text { preparation } \\
\text { Lesson }\end{array}$} & $\begin{array}{c}\text { The Total planning and } \\
\text { preparation Lesson }\end{array}$ & 6.583 & 4.000 & 2.583 & 4.56 & 0.01 \\
\hline & Appointing goals & 21.083 & 9.600 & 11.483 & 1.861 & 0.373 \\
\hline & $\begin{array}{l}\text { Preparing and applying } \\
\text { Lesson }\end{array}$ & 27.667 & 13.600 & 14.067 & 3.003 & 0.001 \\
\hline \multirow{4}{*}{$\begin{array}{c}\text { Implementing } \\
\text { lesson }\end{array}$} & $\begin{array}{l}\text { The Total Implementing } \\
\text { Lesson }\end{array}$ & 11.167 & 6.000 & 5.167 & 2.237 & $\mathbf{0}$ \\
\hline & Introductory part & 19.833 & 11.700 & 8.133 & 0.584 & $\mathbf{0}$ \\
\hline & Main part & 5.75 & 3.700 & 2.05 & 1.406 & $\mathbf{0}$ \\
\hline & Final part & 36.75 & 21.400 & 15.35 & 0.366 & $\mathbf{0}$ \\
\hline & Calendar & 8.833 & 5.600 & 3.233 & 0.839 & 0.001 \\
\hline & Personality & 44.58 & 20.500 & 24.083 & 2.538 & 0 \\
\hline & Total & 117.833 & 61.100 & 56.733 & 6.075 & $\mathbf{0}$ \\
\hline
\end{tabular}

According to table (6) there were statistical significant differences in all dimensional measurement between the second experimental group and control group directed to experimental group in the most variables of research except axe "appointing goals" whereas the significant level values ranged between $(0.001,00.0)$ and less than the moral level 0.05 , except the significant level in axe "appointing goals " that reached to 0.373 which also more than the moral level (0.05)

Table (7): Significant differences in the dimensional measurement between the third experimental group (kinetic learning style) and the control group

\begin{tabular}{|c|c|c|c|c|c|c|}
\hline \multicolumn{2}{|c|}{ Dependent Variable } & $\begin{array}{c}\text { (I) } \\
\text { GROUP } \\
\text { Mean }\end{array}$ & $\begin{array}{c}(\mathbf{J}) \\
\text { GROUP } \\
\text { Mean }\end{array}$ & $\begin{array}{c}\text { Mean } \\
\text { Difference } \\
\text { (I-J) }\end{array}$ & $\begin{array}{l}\text { Std. } \\
\text { Error }\end{array}$ & Sig. \\
\hline \multirow{3}{*}{$\begin{array}{c}\text { planning and } \\
\text { preparation } \\
\text { Lesson }\end{array}$} & $\begin{array}{c}\text { The Total planning and } \\
\text { preparation Lesson }\end{array}$ & 8.875 & 4.000 & 16.025 & 5.052 & 0.008 \\
\hline & Appointing goals & 19.833 & 9.600 & 4.875 & 2.061 & 0.058 \\
\hline & $\begin{array}{c}\text { Preparing and } \\
\text { applying Lesson }\end{array}$ & 29.625 & 13.600 & 11.15 & 3.327 & 0.005 \\
\hline \multirow{4}{*}{$\begin{array}{l}\text { Implementing } \\
\text { lesson }\end{array}$} & $\begin{array}{c}\text { The Total } \\
\text { Implementing Lesson }\end{array}$ & 10.875 & 6.000 & 16.6 & 2.478 & $\mathbf{0}$ \\
\hline & Introductory part & 21.125 & 11.700 & 4.875 & 0.647 & $\mathbf{0}$ \\
\hline & Main part & 6.000 & 3.700 & 9.425 & 1.558 & $\mathbf{0}$ \\
\hline & Final part & 38.000 & 21.400 & 2.3 & 0.405 & $\mathbf{0}$ \\
\hline \multicolumn{2}{|r|}{ Calendar } & 8.750 & 5.600 & 3.15 & 0.929 & 0.004 \\
\hline \multicolumn{2}{|c|}{ Personality } & 42.625 & 20.500 & 22.125 & 2.812 & $\mathbf{0}$ \\
\hline \multicolumn{2}{|c|}{ Total } & 119.000 & 61.100 & 57.9 & 6.73 & $\mathbf{0}$ \\
\hline
\end{tabular}


Total (8): Significant differences between the four research groups in the dimensional measurement of the under research variables

\begin{tabular}{|c|c|c|c|c|c|c|c|}
\hline \multicolumn{2}{|c|}{\begin{tabular}{|l} 
Dependent Variable \\
\end{tabular}} & & Df & $\begin{array}{c}\text { Sum of } \\
\text { Squares }\end{array}$ & $\begin{array}{l}\text { Mean } \\
\text { Square }\end{array}$ & $\mathbf{F}$ & Sig. level \\
\hline \multirow{9}{*}{$\begin{array}{c}\text { planning } \\
\text { and } \\
\text { preparation } \\
\text { Lesson }\end{array}$} & \multirow{3}{*}{$\begin{array}{c}\text { The Total } \\
\text { planning and } \\
\text { preparation } \\
\text { Lesson }\end{array}$} & $\begin{array}{l}\text { Between } \\
\text { Groups }\end{array}$ & 3 & 2316.658 & 772.219 & 6.808 & 0.001 \\
\hline & & Within Groups & 41 & 4650.542 & 113.428 & & \\
\hline & & Total & 44 & 6967.200 & & & \\
\hline & \multirow{3}{*}{$\begin{array}{l}\text { Appointing } \\
\text { goals }\end{array}$} & $\begin{array}{c}\text { Between } \\
\text { Groups }\end{array}$ & 3 & 1080.386 & 360.129 & 19.072 & 0.000 \\
\hline & & Within Groups & 41 & 774.192 & 18.883 & & \\
\hline & & Total & 44 & 1854.578 & & & \\
\hline & \multirow{3}{*}{$\begin{array}{c}\text { Preparing } \\
\text { and applying } \\
\text { Lesson }\end{array}$} & $\begin{array}{l}\text { Between } \\
\text { Groups }\end{array}$ & 3 & 865.228 & 288.409 & 5.864 & 0.002 \\
\hline & & Within Groups & 41 & 2016.417 & 49.181 & & \\
\hline & & Total & 44 & 2881.644 & & & \\
\hline \multirow{12}{*}{$\begin{array}{l}\text { Implementin } \\
\text { g lesson }\end{array}$} & \multirow{3}{*}{$\begin{array}{c}\text { The Total } \\
\text { Implementin } \\
\text { g Lesson }\end{array}$} & $\begin{array}{l}\text { Between } \\
\text { Groups }\end{array}$ & 3 & 2688.994 & 896.331 & 32.852 & 0.000 \\
\hline & & Within Groups & 41 & 1118.650 & 27.284 & & \\
\hline & & Total & 44 & 3807.644 & & & \\
\hline & \multirow{3}{*}{$\begin{array}{c}\text { Introductory } \\
\text { part }\end{array}$} & $\begin{array}{l}\text { Between } \\
\text { Groups }\end{array}$ & 3 & 254.525 & 84.842 & 45.605 & 0.000 \\
\hline & & Within Groups & 41 & 76.275 & 1.860 & & \\
\hline & & Total & 44 & 330.800 & & & \\
\hline & \multirow{3}{*}{ Main part } & $\begin{array}{c}\text { Between } \\
\text { Groups }\end{array}$ & 3 & 1867.936 & 622.645 & 57.708 & 0.000 \\
\hline & & Within Groups & 41 & 442.375 & 10.790 & & \\
\hline & & Total & 44 & 2310.311 & & & \\
\hline & \multirow{3}{*}{ Final part } & $\begin{array}{c}\text { Between } \\
\text { Groups }\end{array}$ & 3 & 47.161 & 15.720 & 21.520 & 0.000 \\
\hline & & Within Groups & 41 & 29.950 & 0.730 & & \\
\hline & & Total & 44 & 77.111 & & & \\
\hline \multirow{3}{*}{\multicolumn{2}{|c|}{ Calendar }} & $\begin{array}{c}\text { Between } \\
\text { Groups }\end{array}$ & 3 & 73.678 & 24.559 & 6.401 & 0.001 \\
\hline & & Within Groups & 41 & 157.300 & 3.837 & & \\
\hline & & Total & 44 & 230.978 & & & \\
\hline \multirow{3}{*}{\multicolumn{2}{|c|}{ Personality }} & $\begin{array}{c}\text { Between } \\
\text { Groups }\end{array}$ & 3 & 4914.575 & 1638.192 & 46.623 & 0.000 \\
\hline & & Within Groups & 41 & 1440.625 & 35.137 & & \\
\hline & & Total & 44 & $6355.2 \mathrm{C3}$ & & & \\
\hline \multirow{3}{*}{\multicolumn{2}{|c|}{ TOTAI }} & $\begin{array}{c}\text { Between } \\
\text { Groups }\end{array}$ & 3 & $\begin{array}{c}31532.41 \\
1\end{array}$ & $\begin{array}{c}10510.80 \\
4\end{array}$ & 52.222 & 0.000 \\
\hline & & Within Groups & 41 & 8252.167 & 201.272 & & \\
\hline & & Total & 44 & $\begin{array}{c}39784.57 \\
8\end{array}$ & & & \\
\hline
\end{tabular}

According to table (8) there were statistical significant differences at the moral level (0.05) between the four research groups in the dimensional measurement of the under research variables, whereas the calculated $(\mathrm{T})$ value more than tabular $(\mathrm{T})$ value and the significant level ranged between $(0.002,00.0)$ and less than the moral level $(0.05)$. 


\section{DISCUSSION}

Discussing the first imposing "there are statistical significant differences between the two measurements pre and post of the experimental group in post measurement in accordance with each style of the educational forms and under used standard.

The second imposing "there are statistical significant differences between experimental group and the controller group in the performance level of teaching skills which applying under the research and in accordance with each style of educational forms and under used standard.

According to previous results in table (1) there were statistical significant differences between the two measurements pre and post of the first experimental group (visual learning style) in all research of the noted teaching skills which directed to the post measurement, and the researcher attributes these result to provide a suitable educational environment for the students with visual learning styles to use visual multimedia during teaching the educational skills which effectively contributed to meet the educational needs of students in accordance with their visual styles, whereas the researcher used the $\mathrm{CD}$ and computer programs that's depending on such programs as "Power Point" which helped to upgrade the students and this consistent with the result

As well as the special programs units described the visual style by away from boring and traditional performance which raises the students boring and that during representing the educational skills on CDs with slow motion and normal photographic by special students and that consists with studies which exposure the effectiveness of modern and creative education styles on the performance of college students and that for breaking the boring and raising students enthusiasm for education ,thereafter the researcher provided a recorded education CDs were available as a reference for each student and utilization them in time (http://www.how-to-study.com, 2006)

The table (2) showed also the statistical significant differences between the two measurements pre and post of the second experimental group (verbal learning style) in axes and clauses of teaching performance notes for post measurement and the researcher referred this result to enhance the direct -verbal which aimed the students with verbal learning styles during teaching the different educational skills and that Consistent with Nobel, David, translated by Al-Amiri (2004). that the student looking for appreciation, so the teacher must show his appreciation to them and confirming they acceptable behavior and that has been done during the passage of the researcher and directing words for reinforcing excellent student by her name, as well as determine the most distinguished students in the unit and be share her for recording parts of the next unit by her voice on the cassette tape heard by the rest of the female group during the application of this unit.

The table (3) showed also the statistical significant differences between the two measurements pre and post of the third experimental group (kinetic learning style) in axes and clauses of teaching performance notes for post measurement and the researcher referred this result to the student division with kinetic learning style to work in groups by using the play style and launch comparison style and make comparisons between students during 
the execution the requested kinetic duties by researcher as well as conducting competitions between groups for spread the competition between students and enhance group performance level.

And that consistent with the study results of Julie (2005) whereas the results confirmed that the participation of students in practical way to work in homogenous, co-operative groups and help them to create the competition esprit that lead to increase the group performance, as well as the students have been recorded more awareness by private teaching and accepted other teaching styles.

In additional to that the dependence on teaching variation entry, which assured the utilization of variation group of teaching strategies were executive by unique or grouped way or within small groups which have "Flexible division of the groups" , the progressive difficult tasks, continuously evaluation activities for evaluate the educational unit skills and concepts in accordance with their kinetic education style by permanent diversity ways and methods for avoiding boring from repetition the same way and that consistent with Jun (2004) the stated that the teaching help the students to success in education by better way and increase they motivation to learn, whereas the students be more success and satisfy when they treated well and by suitable ways with their preparing, needs and teaching to increase the teaching effectiveness

And tables $(5,6,7)$ showed statistical significant differences between the first experimental group (visual learning style) and control group directed to the first group and between second experimental group (verbal learning style) and the control group directed to second experimental group, and between third experimental group (kinetic learning style) and the control group directed to third group and that in all axes and clauses of teaching performance notes.

And that deeply shared to meet student's educational needs which consists with the their educational style for helping them to raise their performance skills to carry on kinetic education as well as using a suitable ways and methods for each style of educational forms and that consist with some reference studies such as Hammouda (2007) stated that the students were represent their knowledge in educational strategies recorded $75 \%$ in the standard deviation more than students were haven't compatibility between educational teaching strategies and their different style and learning.

\section{CONCLUSION:}

According to this search, research imposing, under the samples frame works and methodology, according to statistical treatments, interpreting and discussions the results the researcher figured the following statements:

1- There are statistical significant differences between the two measurements tribal and dimensional of the first experimental group (visual learning style) directed to dimensional measurement in all educational skills under the research with improvement rates ranged between $(54.964 \%$, $231.023 \%$ ).

2- There are statistical significant differences between the two measurements pre and post of the second experimental group (verbal learning style) directed to post measurement in all educational skills under the research with improvement rates ranged between $(50.01 \% 191.34$ $\%)$. 
3- There are statistical significant differences between the two measurements pre and post of the third experimental group (kinetic learning style) directed to post measurement in all educational skills under the research with improvement rates ranged between $(79.49 \%, 190 \%)$.

4- There are statistical significant differences between the two measurements pre and post of the control group directed to post measurement in all educational skills under the research with improvement rates ranged between $(7.5 \%, 57.89 \%)$. 


\section{REFERANCES}

Abdel Latif, Hnan Mohamed (2000): cooperative educational style and its effect on development the educational skills and teacher student worried in the Faculty of Physical Education in Tanta, a field study Journal of Contemporary Education., Fifty-fourth issue, the seventeenth year, February.p10.(in Arabic)

David E.B. (2002).A Strategy for improvement of learning-task presentations, Journal of physical education. Recreation \& Dance, v73n6, Aug .pp:32-35, 42.

Hammouda, Mona (2007): The Effectiveness of the Development Program for a taste of art through learning styles prevalent among students in industrial decorative high school, $\mathrm{PhD}$, College of Education (curriculum and teaching methods), University of Helwan, Cairo, p 95 .(in Arabic)

Julie- Yazici, - Hulya. (2005).A study collaborative learning styles and team learning performance, Education training .v47n3, pp. 216-228.

Jun, Jae hyun. (2004).Believes and practices related to differentiation of special /school for gifted learners. An, Unpublished, PhD, Erick, Dissertation, university of Virginia, p 27.

Mixon, Kevin. (2004). Three Learning styles Four steps to reach them, teaching music.v.11n4, Feb. p 48.

Nobel, S. and David J, translated by Khalid al-Amiri (2004): behavior treatment of the student in classes, Cairo, Dar El farouk for issuing and distribution, $\mathrm{p}$ 35 .

Qamati, Joseph \& Naifeh (2000): psychology classroom learning, Amman, Dar Al Sharqi 1, the first version, pp. 6-7.(in Arabic)

Robert, M. (2001).The Effects of multimedia software instruction and Lecture-based instruction on learning and teaching cues of manipulative skills on preserves physical education teachers. Physical Educator, v58n1, pp: 2-13Late Win.

Your preferred learning style(2006): http://www.how-to-study.com/Learning style.13jun. 